\title{
LARGE-SCALE SPATIAL VARIABILITY IN THE CONTEMPORARY COASTAL SAND AND GRAVEL RESOURCE, SUFFOLK, EASTERN UK
}

\author{
HELENE BURNINGHAM $^{1}$, JON FRENCH ${ }^{1}$ \\ 1. Coastal and Estuarine Research Unit, UCL Department of Geography, University \\ College London, Gower Street, London,WC1E6BT, UK. h.burningham@ucl.ac.uk, \\ j.french@ucl.ac.uk
}

\begin{abstract}
The response of coastal systems to changes in sea level and storm events is often dependent on the availability of sediment and sustainability of sediment supply. This paper analyses the changing sediment resource of a driftaligned shoreline in eastern England, UK, over centennial and decadal timescales. Spatial variability in cross-shore extent and elevational distribution of this mixed sand and gravel system exerts a significant control on the ability of different stretches of this shoreline to respond dynamically to changes in marine forcing. Furthermore, anthropogenic interference has led to the development of unnaturally high beach ridges in some places, which contrasts with the absence of intertidal or supratidal sediment along stretches dominated by seawalls.
\end{abstract}

\section{Introduction}

Vulnerability of coastlines to flood and erosion risk is as much dependent on sediment availability as it is the frequency of storms and surges, and the rate of sea-level rise. In the presence of unlimited sediment supply, coastal sediment systems are able to respond dynamically to changes in coastal processes, with minor hazard for coastal communities. But supply-limited coastlines are often more vulnerable to flooding and inundation, in addition to experiencing enhanced erosion rates. Understanding the nature of sediment budgets can be readily achieved in systems where the boundaries to littoral and on-/offshore movement are clear, for example in highly compartmentalized systems. On drift-aligned coastlines, the problem is more complicated where divides in direction and alongshore changes in rates of transport often necessitate the use of modeled transport rates to derive what are sometimes very approximate representations of the sediment budget.

This situation is well exemplified by the Suffolk coast of eastern England, UK (Fig. 1). Approximately $9 \mathrm{~km}^{2}$ of mixed sand and gravel are accommodated on this $75 \mathrm{~km}$ coast in the form of beaches, beach ridges, cuspate forelands, spits, barriers and dunes. In many these sand and gravel deposits provide the primary protection to significant areas of low-lying, often reclaimed land. 


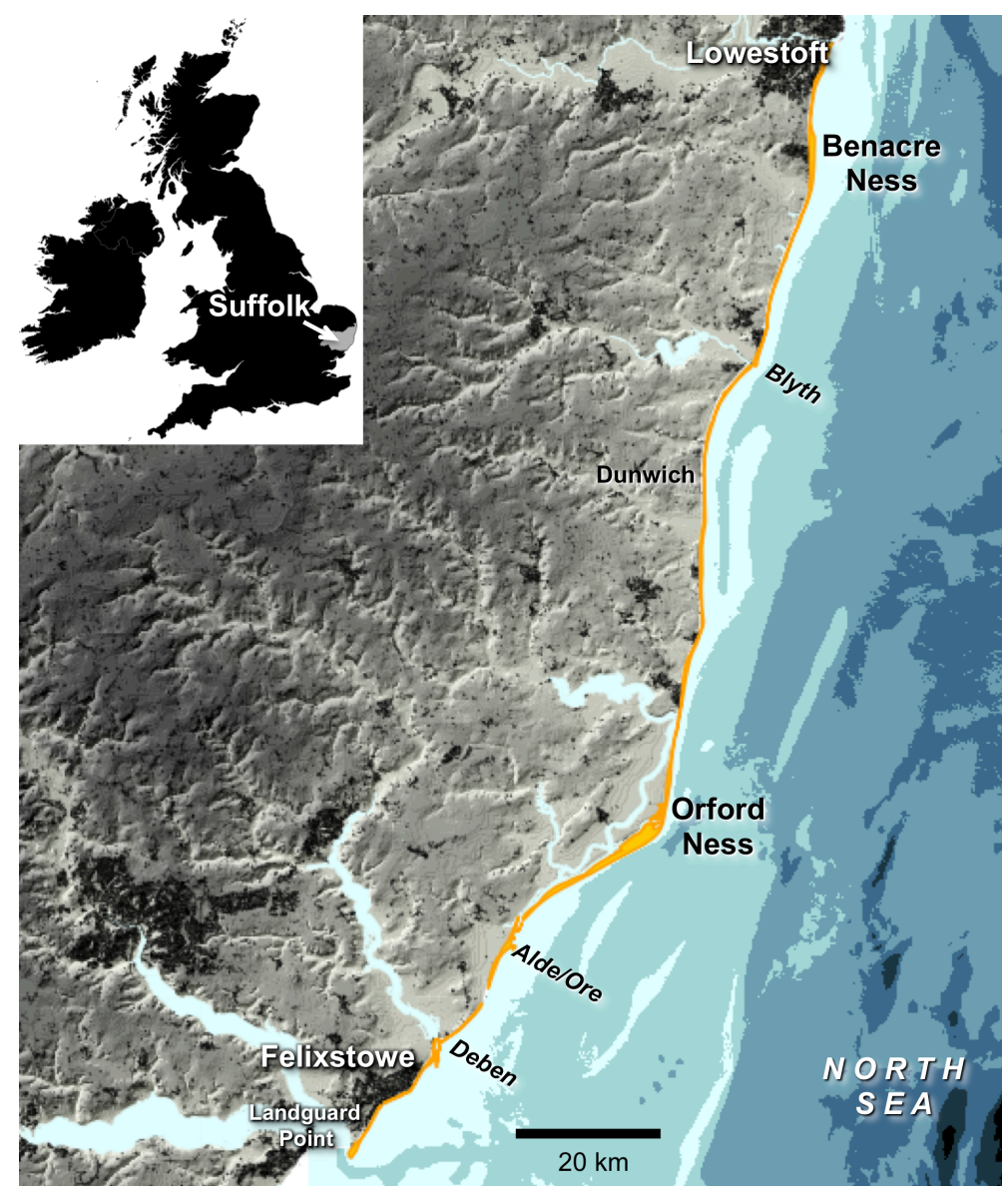

Fig. 1. Distribution of inter- and supra-tidal sand and gravel on the Suffolk coast.

The Suffolk coast is micro- to mesotidal and exposed to the storm wave climate of the southern North Sea, where wave directions are strongly bimodal. The sediment-transport dominance of northeasterlies has, over centuries, led to the development of a north to south, drift-aligned geomorphology where spits and inlets in particular are skewed southward. Coastal change here has been extensively analysed for decades, but this has led to the generation of multiple estimates for sediment transport rates and directions. Recent erosion and near loss of beaches at Felixstowe, south Suffolk has prompted many to question the nature of sediment transport on the whole Suffolk coastline, and in particular, the evidence for contemporary net north to south sediment transfer. 


\section{Research Approach}

This paper investigates the historic and contemporary coastal sand and gravel system between the ports of Lowestoft in the north and Felixstowe in the south (Fig. 1). Gravel and sand extent was digitized from historical mapping (late 1880s) and recent high resolution (1-2 m horizontal interval) lidar and aerial photography. In addition to analysis of change in the planform of the inter- and supra-tidal sand and gravel, a detailed analysis of the lidar data was undertaken to derive the first regional high resolution estimate of sediment volume. The broader geomorphology of the sand and gravel deposits is also evaluated on the basis of geographical variation in beach ridge and barrier topography.

\section{Results}

\section{Contemporary sediment system}

The Suffolk coastal system comprises a near-continuous intertidal and supratidal sedimentary unit. Breaks in the intertidal or supratidal sediment system are most apparent at estuary mouths (Deben, Alde/Ore and Blyth), which naturally divide the shoreline into 4 large-scale units (Fig. 1). Additionally, at a few sites, beach levels in front of rock armour and revetment have fallen sufficiently to remove any continuity in the intertidal or supratidal system. The total volume of this sediment system, calculated cross-shore between mean low water (MLW) and cliff toe/backbarrier extents, is estimated at $35 \times 10^{6} \mathrm{~m}^{3}$ (based on the sum of topographic transect volumes, spaced $100 \mathrm{~m}$ alongshore). Approximately $45 \%$ of this volume $\left(16 \times 10^{6} \mathrm{~m}^{3}\right)$ lies above mean high water (MHW) and about a third is $\left(11 \times 10^{6} \mathrm{~m}^{3}\right)$ is supratidal, lying above highest astronomical tides (HAT).

The alongshore distribution of the coastal sediment system exhibits significant geographical variability (Fig. 2). Orfordness is the primary store of inter- and supratidal sediment, with a peak in the volume and width where the foreland reaches its most eastward extent (Fig. 1). There are peaks in volume around most of the estuary inlets: at Landguard Point (the north margin of the Stour/Orwell inlet), at Bawdsey and Felixstowe Ferry (north and south of the Deben inlet respectively), at Shingle Street (on the south side of the Alde/Ore inlet) and also around the Blyth inlet. Other notable accumulations are evident north and south of Thorpeness and at Benacre Ness (south of Lowestoft). The cliff-dominated shoreline between Southwold and Benacre Ness comprises a series of small barriers where sediment volumes are locally high, but in the broader context represents only a small proportion of the total sediment system. 


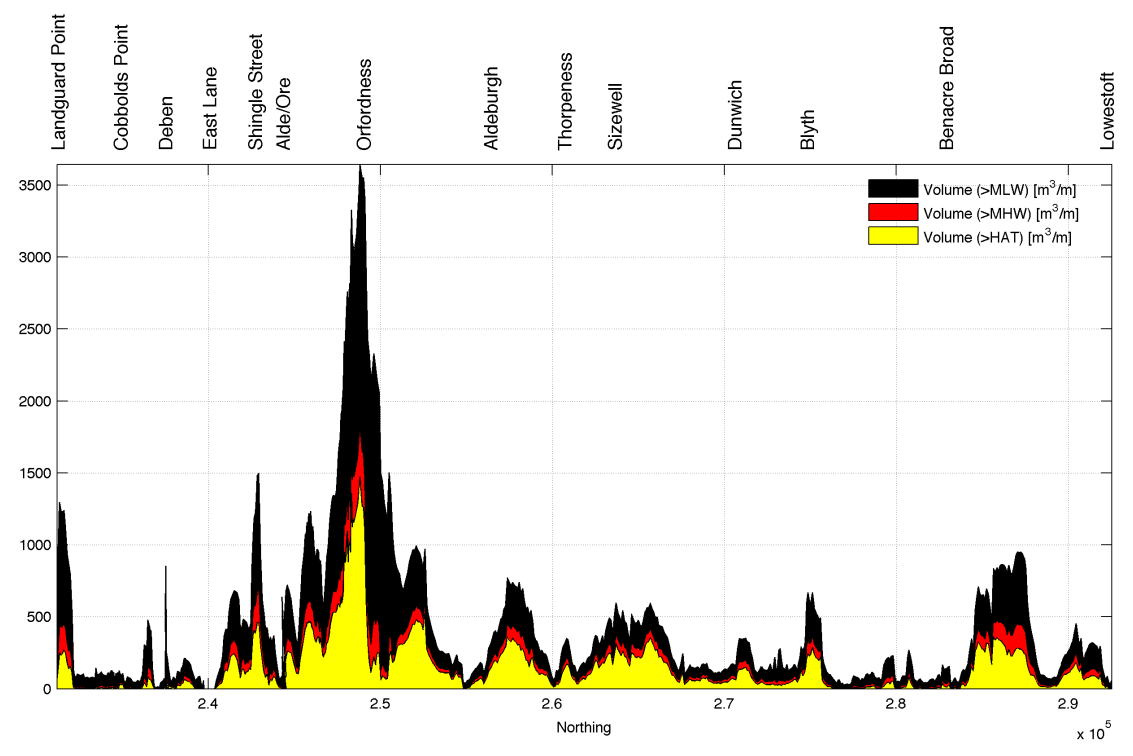

Fig. 2. Alongshore variation in the volume of the coastal sediment system (above MLW) at $1 \mathrm{~m}$ wide transects spaced approximately $100 \mathrm{~m}$ intervals.

The alongshore volume variations are partly a product of the width of the sediment system, but are also related to the topography of the backshore/beach ridge environment. This topographic variability is particularly interesting, and Fig. 3 shows the vertical structure of the sediment system as an absolute elevation distribution (above MLW), and as an elevation distribution scaled by volume and width. The variability shown in Fig. 2 is still apparent, but this further analysis shows that some parts of the system attain a significantly greater height than others. These are primarily the result of human intervention where backshore ridges have been re-profiled to provide a steeper, higher barrier. At Sudbourne Beach (between Orfordness and Aldeburgh), an artificially high ridge has provided protection to Ministry of Defence infrastructures for decades. Around Sizewell, beach and dune sediments overlay an artificial sand embankment that provides some protection to Sizewell nuclear power station and the wetlands at Minsmere. 
Elevation ( $m>M L W$ )

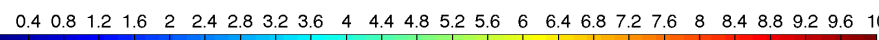

Lowestoft

Scaled by width

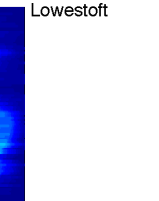

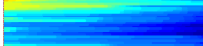

Benacre Broad

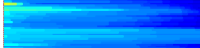

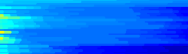

$x+\frac{10}{20}$

Blyth

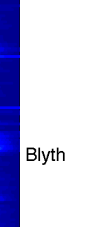

$=\frac{19}{2+3}$

Dunwich
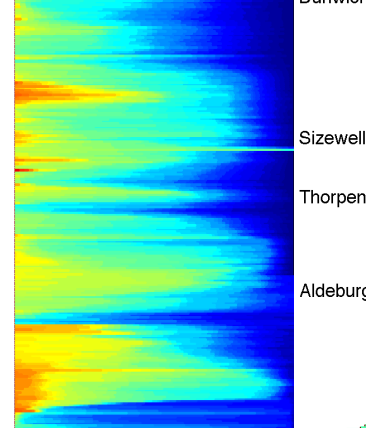

Sizewell

Thorpeness



Scaled by volum

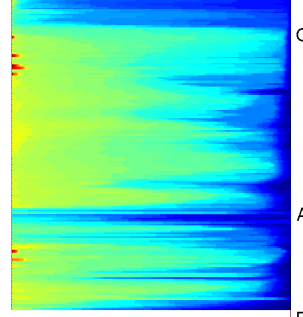

Orfordness

Aldeburgh


Alde/Ore
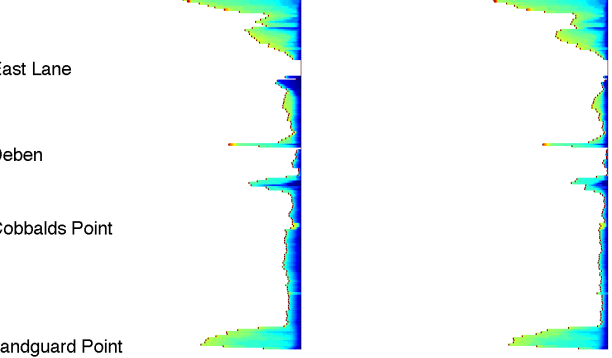

Fig. 3. Height distribution (above MLW) of the contemporary Suffolk coastal sediment system, showing the absolute (relative) distribution, and distributions scaled by width and volume. 
The height distribution from Orfordness to the Alde/Ore is perhaps a better reflection of the natural topographic structure of the beach ridge environment. A similar elevation distribution is also found at Landguard Point (south of Felixstowe), along the Shingle Street barrier (south of the Alde/Ore) and between Aldeburgh and Thorpeness. Benacre Ness is notably different, having a large volume that is distributed over lower elevations than at the other main forelands. This might be due to the more mixed sediment population at Benacre Ness (formed of sand and gravel), in comparison to Orfordness (almost entirely fine to very coarse gravel (Carr, 1970; McGregor and Green, 1990)). The region of Orfordness immediately north of the 'ness' is comparable in structure (though not volume or width) to the barriers of north Suffolk (fronting the Easton, Covehithe and Benacre Broads), and little sediment occurs at the higher elevations. These sites are more vulnerable to surge and storm events than elsewhere. Where the sediment system lies primarily within the foreshore (where volume/width are small), overall elevations are also much lower.

\section{Historical change in the coastal sediment system}

The cross-shore extent of the coastal sediment system reveals a broad similarity between the late 19th century and present day (Fig. 4). Orfordness maintains the most significant lateral extent, which is an order of magnitude larger than elsewhere on this coast. It is also clear that some reshaping and reorganisation of sediments has taken place, most notably, erosion of Orfordness, erosion north of Benacre Broad and loss of sediment along the East Lane frontage. The only evidence of significant expansion in the system is between Benacre Broad and Lowestoft, where the Benacre Ness foreland has migrated northward. The mean width (to MLW) of the late 19th century system was $140 \mathrm{~m}$, and is presently $136 \mathrm{~m}$, suggesting an overall decrease in the width of the system. But the mean is significantly skewed by the few instances of extreme widths around the main forelands. Considering the median width instead, the system has decreased from $91 \mathrm{~m}$ to $77 \mathrm{~m}$, which might better reflect a broad recession in mean low water.

The total areal extent of the historical (c. 1880s) sediment system, including the intertidal zone (to MLW) was $9.61 \times 10^{6} \mathrm{~m}^{2}$, compared with $8.96 \times 10^{6} \mathrm{~m}^{2}$ for the modern system (Table 1). This reduction in total area is not matched in the supratidal system (to MHW), which increased slightly from $7.18 \times 10^{6} \mathrm{~m}^{2}$ in the $1880 \mathrm{~s}$ to $7.52 \times 10^{6} \mathrm{~m}^{2}$ at present. This contrasting behaviour between the reduction in the total sediment system (by 6.7\%) and growth in the supratidal system (by 4.7\%) implies foreshore steepening - that the intertidal zone has narrowed over the last 130 years. This means that proportionately, a larger area (and presumably volume) is held in the supratidal system presently (84\%) than in the late 19th century (75\%). This change in exhibited along all stretches of the Suffolk coast, but is perhaps most evident further where the sediment system 
is less extensive. Between Landguard Point and the Alde/Ore entrance, only c. $45 \%$ of the sediment system area was held in the supratidal zone in the late $1800 \mathrm{~s}$, but the proportion has increased to about $64 \%$ currently. This is in contrast to a change from about $80 \%$ to $90 \%$ north of the Alde/Ore.

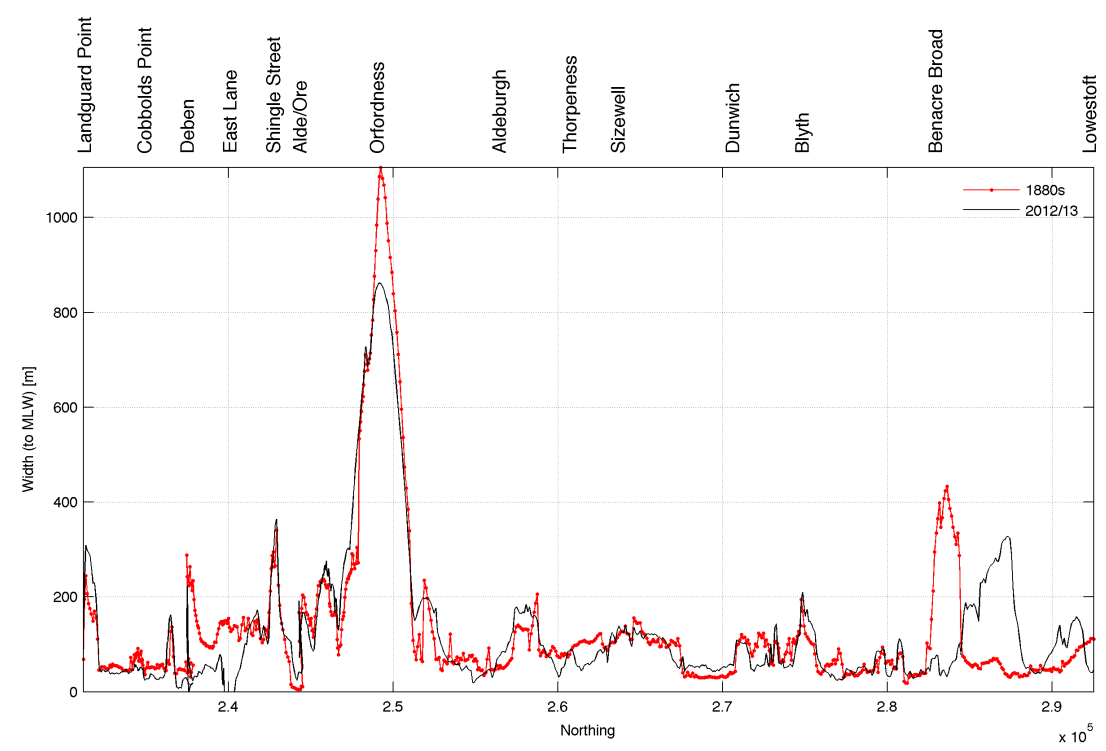

Fig. 4. Comparison of cross-shore extent of the Suffolk coastal sediment system landward of mean high water (MLW) between the 1880s and 2012/13.

One interpretation of these metrics is that the supratidal sediment system has functioned as a net sediment sink over the last 130 years. Considering the four main shoreline stretches (divided by the estuary mouths), in all cases change in supratidal area $(>\mathrm{MHW})$ has been greater than that in total area $(>\mathrm{MLW})$. This implies widespread historical narrowing of the intertidal along much of this coast. The only stretch to have experienced a reduction in the supratidal area is the long section between the Alde/Ore and the Blyth entrances. Here, the sediment system has suffered a net loss in both the intertidal and supratidal extent. This appears to be associated with the reshaping and cannibalization of Orfordness (Fig. 4). Despite evidence of increasing supratidal storage along the Suffolk coast, Orfordness appears to be acting as a sediment source, possibly supplying maintenance and growth elsewhere along this coastline.

In contrast, the stretch further north (Blyth entrance to Lowestoft) has expanded by $14 \%$ in total area and $23 \%$ in supratidal area. But the imbalance in area change continues to imply broad-scale steepening. The expansion in sediment system area might be a consequence of large-scale erosion north of Southwold 
(Burningham and French, 2014). Historically, this has contributed large volumes of sediment to the system (Burningham and French, 2015), 60-95\% of which would be sand and gravel, thereby potentially adding to the intertidal and supratidal sediment system volume (James and Lewis, 1996).

Table 1. Historical change in the area of the Suffolk coastal sediment system, relative to various tidal datum levels.

\begin{tabular}{|c|c|c|c|c|c|}
\hline & \multicolumn{5}{|c|}{ Area (to MLW) $\left[\mathrm{m}^{2}\right]$} \\
\hline & Suffolk & $\begin{array}{c}\text { Landguard to } \\
\text { Deben }(\sim 10 \mathrm{~km})\end{array}$ & $\begin{array}{l}\text { Deben to Alde/ } \\
\text { Ore }(\sim 10 \mathrm{~km})\end{array}$ & $\begin{array}{c}\text { Alde/Ore to } \\
\text { Blyth }(\sim 36 \mathrm{~km})\end{array}$ & $\begin{array}{l}\text { Blyth to Lowestoft } \\
\text { ( } \sim 19 \mathrm{~km})\end{array}$ \\
\hline $1880 s$ & $9,605,496$ & 597,978 & $1,278,898$ & $6,107,258$ & $1,621,362$ \\
\hline 2012/13 & $8,963,092$ & 602,129 & 928,126 & $5,584,186$ & $1,848,651$ \\
\hline \multirow[t]{3}{*}{ Change } & $\begin{array}{c}-642,404 \\
(-7 \%)\end{array}$ & $\begin{array}{c}4,151 \\
(+1 \%)\end{array}$ & $\begin{array}{c}-350,772 \\
(-27 \%)\end{array}$ & $\begin{array}{c}-523,072 \\
(-9 \%)\end{array}$ & $\begin{array}{r}227,289 \\
(+14 \%)\end{array}$ \\
\hline & \multicolumn{5}{|c|}{ Area (to MHW) $\left[\mathrm{m}^{2}\right]$} \\
\hline & Suffolk & $\begin{array}{c}\text { Landguard to } \\
\text { Deben }(\sim 10 \mathrm{~km})\end{array}$ & $\begin{array}{l}\text { Deben to Alde/ } \\
\text { Ore }(\sim 10 \mathrm{~km})\end{array}$ & $\begin{array}{c}\text { Alde/Ore to } \\
\text { Blyth }(\sim 36 \mathrm{~km})\end{array}$ & $\begin{array}{c}\text { Blyth to Lowestoft } \\
\text { ( } \sim 19 \mathrm{~km})\end{array}$ \\
\hline $1880 s$ & $7,181,022$ & 266,372 & 506,876 & $5,204,375$ & $1,203,399$ \\
\hline $2012 / 13$ & $7,521,251$ & 386,178 & 595,366 & $5,055,076$ & $1,484,631$ \\
\hline Change & $\begin{array}{c}340,229 \\
(+5 \%)\end{array}$ & $\begin{array}{l}119,806 \\
(+45 \%)\end{array}$ & $\begin{array}{l}88,490 \\
(+17 \%)\end{array}$ & $\begin{array}{c}-149,299 \\
(-3 \%)\end{array}$ & $\begin{array}{r}281,232 \\
(+23 \%)\end{array}$ \\
\hline
\end{tabular}

The coastline between the Deben and Alde/Ore entrances has experienced the largest (relative) reduction in total area. The supratidal system along this stretch represents a smaller proportion of the total area in comparison to further north, and this has increased a small amount over the last 130 years. Most significant, however, is the extent of erosion across the intertidal zone. Ongoing extension of defences here has led to an interruption in the continuity of the alongshore sediment system at East Lane (as shown in Fig. 3). The foreshore in the vicinity of East Lane overlays a wave cut platform in London Clay. At low tide this is often visible on the lower foreshore. This platform continues under the rock armour along the East Lane frontage, and there is little evidence of any clastic/littoral sediment maintaining a presence across this platform in the lower foreshore/nearshore. The sediment feed between the south end of the Shingle Street barrier and the north end of Bawdsey Beach is weak, if not non-existent. 


\section{Recent change in the coastal sediment system}

Comparison of the recent coastal sediment system (2012/13) with that from 1999 again shows broad similarity over this short timescale (Fig. 5). In this case, only the high supratidal system (above HAT) is considered due to the lack of intertidal coverage in the 1999 lidar survey, but both width and volume can be considered. The foci of change are similar to those emerging from the historical analysis. Significant changes are evident at Benacre Ness (south of Lowestoft) where northward migration is manifest as negative change on the south side of the foreland and large scale positive change to the north. Significant change is also evident around Orfordness, where the foreland has lost sediment but Sudbourne beach to the north of the foreland has gained sediment. The supratidal sediment volume along the cliff-backed coast of north Suffolk has remained quite stable, particularly in comparison to the East Lane - Bawdsey stretch, where significant loss of the non-cliff supratidal deposit has been experienced. Trends in volume largely match those in width, which implies that there is little vertical accretion on existing beach ridges.



Fig. 5 Change in volume and width of the supratidal ( $>$ HAT) sediment system from 1999 to

$$
\text { 2012/13. }
$$

Volumetric change in the entire supratidal sediment system over this roughly 14 year period is estimated at $-29,326 \mathrm{~m}^{3}$, which equates to a rate of loss of 2,095 $\mathrm{m}^{3} \mathrm{yr}^{-1}$ (Table 2). The loss is evident in the south and north, but along the Alde/Ore to Blyth stretch, there is some evidence of an increase in supratidal 
volume. Given the size of the system, these total changes are likely to be well within the error margin. Analysis of the impact of a $\pm 10 \mathrm{~cm}$ vertical error in topography (based on quoted lidar accuracy) on volume calculations puts the change analysis in an uncertainty context (Table 2). Overall, the volumetric analysis suggests that despite significant localised change (evident alongshore; Fig. 4), the overall sediment budget of the supratidal (non-cliff environment) is stable.

Table 2 Short-term changes in the volume of the coastal sediment system, relative to various tidal datum levels. Volume calculations based on $100 \mathrm{~m}$ interval shore-normal topographic transects. Uncertainty estimated using a $\pm 10 \mathrm{~cm}$ (lidar accuracy) elevation shift.

\begin{tabular}{lccccc}
\hline & Suffolk & $\begin{array}{c}\text { Landguard } \\
\text { to Deben } \\
(\sim \mathbf{1 0 k m})\end{array}$ & $\begin{array}{c}\text { Volume (to HAT) } \\
\text { Deben to } \\
\text { Alde/Ore } \\
(\sim \mathbf{1 0 k m})\end{array}$ & $\begin{array}{c}\text { Alde/Ore to } \\
\text { Blyth } \\
(\sim 37 \mathbf{k m})\end{array}$ & $\begin{array}{c}\text { Blyth to } \\
\text { Lowestoft } \\
(\sim \mathbf{2 0 k m})\end{array}$ \\
\hline $\mathbf{1 9 9 9}$ & $11,717,974$ & 291,300 & 795,123 & $8,941,613$ & $1,689,936$ \\
$\mathbf{2 0 1 2} / \mathbf{1 3}$ & $11,688,648$ & 279,741 & 796,427 & $8,986,322$ & $1,626,156$ \\
Change & $-29,326$ & $-11,559$ & 1,304 & 44,709 & $-63,780$ \\
Uncertainty & $\pm 715,620$ & $\pm 31,140$ & $\pm 54,990$ & $\pm 505,150$ & $\pm 124,330$ \\
\hline
\end{tabular}

The vertical structure of the supratidal system also varies geographically (Fig. 6). The Deben to Blyth shoreline has an elevation distribution that is skewed to higher elevations (around a mode at HAT +1.8 to HAT $+2.5 \mathrm{~m}$ ) than the coast to the north or south. Between Landguard Point and the Deben, the topography is near-normally distributed around an elevation at about HAT $+0.8 \mathrm{~m}$ whereas modal elevations between the Blyth and Lowestoft are about HAT +0.2 to HAT $+1 \mathrm{~m}$. Interestingly, the change in elevation distribution between 1999 and 2012/13 is most significant in the far north, along the Blyth to Lowestoft stretch. This is the region where Benacre Ness (Burningham and French, 2014) is located, and here the sediment distribution has become more skewed to lower elevations (Fig. 6). It is likely that this reflects reshaping and reorganization of this foreland where older, higher beach ridges are eroded and sediment is moved into newly created, lower elevation ridges. No other parts of this coast show this behaviour and between the Deben and the Blyth there is actually a slight shift to higher elevations. Aggregating the elevation distribution over long stretches of coast is likely to mask more significant changes, but the overall story for the Suffolk coast is one of minimal overall change, in the short-term, and a balance in sediment budget. 

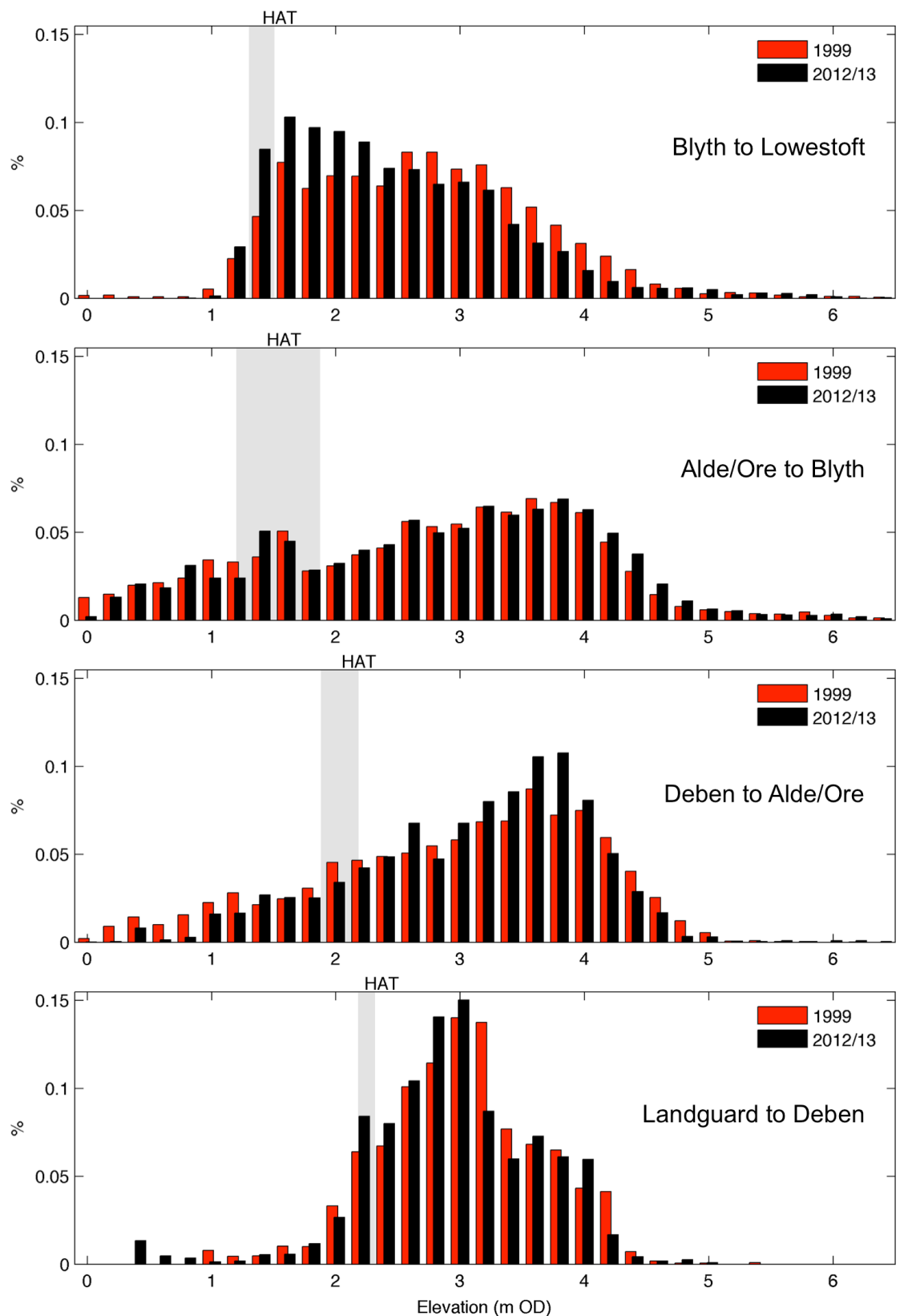

Fig. 6 Comparison of the supratidal coastal sediment system elevation frequency distributions (between 1999 and 2012/13) for the four main stretches of the Suffolk coast. 


\section{Discussion and conclusion}

The barrier beaches of mid and north Suffolk are vulnerable to storm overtopping and breaching, in places only attaining a height of about $1 \mathrm{~m}$ above the local level of mean high water. A storm surge event in December 2013 generated water levels similar to those experienced in the historic 1953 surge (Rossiter, 1954), and caused breaching of some of the barriers, and marine flooding of freshwater marshes. Washover fans are a morphological feature of the contemporary Suffolk barriers, despite decades of artificial steepening for coastal protection. Recent breaching episodes (such as in 2007; Pye and Blott, 2009) has diminished barrier topography, which has increased their vulnerability to further overwash and backbarrier flooding. This is acutely evident in the topography presented here, where the barriers of north Suffolk are particularly low relative to the tidal frame.

Analysis of the Suffolk coastal sand and gravel system shows a historical reduction in the total sediment area, but an increase in the supratidal area. Shoreline recession and progradation are both locally prevalent, with some evidence for a region-wide foreshore steepening. In the case of Benacre Ness, an entire foreland has moved 2 to $3 \mathrm{~km}$ alongshore (Burningham and French, 2014). Both the historic and contemporary coastal sediment systems are unevenly distributed alongshore, which has led to a mix of broad beach ridge plains, thin backshore ridges and narrow barriers. The overall geography of these has shown little change, but the continuity of the sediment system has been compromised by the construction of hard defense structures such as rock revetments and beach groynes. Historically, the sediment system sustained both an intertidal and supratidal alongshore connectivity interrupted only by inlets. There now are at least two sites where minimal intertidal and no supratidal sand and gravel deposit remains. The contemporary coastal sediment system has therefore become much more compartmentalised.

Analysis of sediment volumes suggests a fairly stable supratidal sediment budget for the Suffolk coast overall. Again, this is despite both recession and progradation that have been locally significant. Alongshore sediment transport is evident around the main forelands where erosion on the southern extent of the foreland is almost balanced by accretion on the north side. In the case of Benacre Ness, this has resulted in an alongshore, northward shift in the position of the foreland, but at Orfordness, the consequence is localized reshaping of the foreland. It seems clear, though, that despite considerable shoreline variability sediment volumes are being more-or-less maintained.

The Suffolk sediment system is complex and its functioning must be understood for effective coastal management in the future. High spatial resolution analysis 
at a broad spatial scale makes it possible to evaluate local changes in the context of regional sediment budgets and to disaggregate local variability from the progressive shoreline tendencies that give rise to the most challenging management problems.

\section{Acknowledgements}

This paper has arisen out of analysis funded by NERC (http://www.nerc.ac.uk) as part of the Integrating COAstal Sediment SysTems (iCOASST) project (NE/J005541/1). The iCOASST project draws on additional support, including provision of datasets, from the Environment Agency (http://environmentagency.gov.uk) as an embedded stakeholder. The work has been extended as part of a Crown Estate-funded project on the shoreline and shoreface dynamics of the Suffolk coast.

\section{References}

Burningham, H. and French, J. R. (2014). "Travelling forelands: complexities in drift and migration patterns.” Journal of Coastal Research SI70, 102-108.

Burningham, H. and French, J. R. (2015). "Shoreline - Shoreface Dynamics on the Suffolk Coast." Crown Estate.

Carr, A.P. (1970). "The evolution of Orfordness, Suffolk, before 1600 AD: geomorphological evidence." Zeitschrift für Geomorphologie, Neue Folge, 14, 289-300.

James, J.W.C. and Lewis, P.M. (1996). "Sediment input from coastal cliff erosion.” Technical Report 577/4/A, Environment Agency, Peterborough, $67 \mathrm{pp}$.

McGregor, D.F.M. and Green, C.P. (1990). "Composition of Orfordness shingle." Proceedings of the Geologists Association, 101 (3), 259-263.

Pye, K. and Blott, S. J. (2009). "Progressive Breakdown of a Gravel-Dominated Coastal Barrier, Dunwich-Walberswick, Suffolk, U.K.: Processes and Implications." Journal of Coastal Research 25 (3), 589-602.

Rossiter, J.R. (1954). "The North Sea Storm Surge of 31 January and 1 February 1953." Philosophical Transactions of the Royal Society A, 246, 371-400. 